\title{
Mycorrhizal associations of nursery grown Scots pine (Pinus sylvestris L.) seedlings in Poland
}

\author{
Michał IWAŃsKI, Maria RUdAWsKA*, Tomasz LESKI \\ Institute of Dendrology, Polish Academy of Sciences, Kórnik, Poland
}

(Received 26 October 2005; accepted 27 January 2006)

\begin{abstract}
We investigated the species richness and composition of mycorrhizal fungi naturally colonizing one- and two-year-old Pinus sylvestris L. seedlings from four bare-root nurseries in Poland. We hypothesized that both edaphic factors and seedling age would affect ectomycorrhizal (ECM) community structure. We assessed the relative abundance of mycorrhizal morphotypes and distinguished ECM fungi present on root tips using RFLP (restriction fragment length polymorphism) of the ITS (internal transcribed spacer) of fungal rDNA. Most of the RFLP types were identified by comparing RFLP patterns with reference data obtained from regional sporocarps and isolates of ectendomycorrhizal species. Samples of unidentified RFLP types and representatives of suilloid RFLP patterns were sequenced and compared with available sequences. Overall, we identified 13 fungal species, with species richness varying from two to eight species among nurseries. The dominant species in each examined nursery were Wilcoxina mikolae and Thelephora terrestris. Suilloid fungi were also abundant in most of the nurseries. S. variegatus was the most frequent suilloid species among the nurseries. Seedling age affected the relative abundance of ECM species to some extent. Principal component analysis (PCA) revealed a lack of apparent correlations between the relative abundances of species and edaphic factors. Factors that may contribute to the maintenance of ECM community structure are discussed.
\end{abstract}

forest nursery / mycorrhiza / ITS-RFLP / Scots pine

\begin{abstract}
Résumé - Associations mycorhiziennes des semis de pin sylvestre (Pinus sylvestris L.) en pépinière en Pologne. Nous avons étudié la richesse spécifique et la composition des champignons mycorhiziens colonisant naturellement des semis de Pinus sylvestris L. âgés de un et deux ans dans quatre pépinières de production de plants à racines nues en Pologne. Nous avons fait l'hypothèse que ensemble les facteurs édaphiques et l'âge des semis affecteraient la structure de la communauté ectomycorhizienne (ECM). Nous avons déterminé l'abondance relative des morphotypes mycorhiziens et distingué les champignons ECM présents dans les pointes racinaires en utilisant RFLP de ITS de l'ADNr fongique. La plupart des types RFLP ont été identifiés en comparant les modèles RFLP avec des données de référence obtenues de sporocarpes régionaux et isolés d'espèces ectoendomycorhiziennes. Des échantillons de types RFLP non identifiés et de modèles représentatifs de suilloides RFLP ont été séquencés et comparés avec les séquences disponibles. Globalement, nous avons identifié 13 espèces fongiques, avec une richesse spécifique variant de deux à huit espèces parmi les pépinières. Dans chaque pépinière étudiée, les espèces dominantes étaient Wilcoxina mikolae et Thelephora terrestris. Les champignons suilloides étaient aussi abondants dans la plupart des pépinières. S. variegatus était l'espèce suilloide la plus fréquente parmi les pépinières. L'âge des semis affecte dans une certaine mesure l'abondance relative des espèces ECM. Une analyse en composantes principales (PCA) révèle un manque apparent de corrélations entre l'abondance relative des espèces et les facteurs édaphiques. Les facteurs qui peuvent contribuer au maintien de la structure de la communauté des ECM sont discutés.
\end{abstract}

pépinière forestière / mycorhize / ITS-RFLP / pin sylvestre

\section{INTRODUCTION}

Most forest trees in coniferous boreal and temperate forests live in symbiosis with ectomycorrhizal fungi (ECM). Ectomycorrhizal associations are important in nutrient cycling, particularly in the acquisition and transfer of nutrients from heterogeneous resources [47]. Protection from soil-borne pathogens, especially in the early stages of tree development, is also considered as an important function of mycorrhizal symbiosis [12].

In contrast to host plant communities, communities of ECM fungi are characterized by high biodiversity, associated with a broad range of capabilities for uptake of organic and inor-

\footnotetext{
*Corresponding author: mariarud@man.poznan.pl
}

ganic forms of nitrogen and the carbohydrate demands on the host $[1,4]$. Consequently, the physiological diversity of ECM fungi enables niche differentiation on the basis of host age and specificity [3], soil conditions, stress factors [5, 13, 44], and propagation strategies $[15,50]$.

Forest nurseries in Poland produce over 1.3 billion tree seedlings per year. Scots pine seedlings constitute the majority of production and serve as a main source for reforestation of over 56000 ha per year. Mycorrhizal fungi, naturally colonizing seedlings in nurseries, are essential for the establishment and survival of young trees for at least several years after out planting $[7,9,24,49]$. In afforestation of post-agricultural lands (approximately 20000 ha per year in Poland), where no ECM inoculum is present, the importance of nursery-adapted ECM fungi is even more pronounced. 
Table I. Description of the nurseries (P - Przymuszewo, S - Solec Kujawski, Z - Zlotow, O - Okonek).

\begin{tabular}{|c|c|c|c|c|}
\hline \multirow{2}{*}{ Stand characteristics } & \multicolumn{4}{|c|}{ Nursery } \\
\hline & $\mathrm{P}$ & $\mathrm{S}$ & $\mathrm{Z}$ & $\mathrm{O}$ \\
\hline Nursery location & $\begin{array}{c}53^{\circ} 16^{\prime} \mathrm{N} ; \\
17^{\circ} 34^{\prime} \mathrm{E}\end{array}$ & $\begin{array}{c}53^{\circ} 04^{\prime} \mathrm{N} ; \\
18^{\circ} 14^{\prime} \mathrm{E}\end{array}$ & $\begin{array}{c}53^{\circ} 21^{\prime} \mathrm{N} ; \\
17^{\circ} 03^{\prime} \mathrm{E}\end{array}$ & $\begin{array}{c}53^{\circ} 31^{\prime} \mathrm{N} ; \\
16^{\circ} 51^{\prime} \mathrm{E}\end{array}$ \\
\hline Mean annual temperature $\left({ }^{\circ} \mathrm{C}\right)$ & 7.4 & 7.4 & 8.8 & 7.5 \\
\hline Mean annual precipitation (mm) & 596 & 500 & 580 & 608 \\
\hline Vegetation period $(\mathrm{d})$ & 210 & 212 & 216 & 211 \\
\hline Nursery age (yr) & 29 & 30 & 26 & 11 \\
\hline \multirow[t]{2}{*}{ Fertilization $(\mathrm{kg} / \mathrm{ha} / \mathrm{yr})$} & N-150 (1-yr)* & N-120 (1-yr) & N-55 (1-yr) & N-200 (1-yr) \\
\hline & N-150 (2-yr) ${ }^{*}$ & N-100 (2-yr) & $\mathrm{N}-45(2-\mathrm{yr})$ & $\mathrm{N}-100(2-\mathrm{yr})$ \\
\hline Irrigation & No & Yes & Yes & Yes \\
\hline Fungicide aplication & $1 \cdot \mathrm{yr}^{-1}$ & $2 \cdot \mathrm{yr}^{-1}$ & $2 \cdot \mathrm{yr}^{-1}$ & $1 \cdot \mathrm{yr}^{-1}$ \\
\hline Crop rotation & Yes & Yes & Yes & No \\
\hline
\end{tabular}

${ }^{*}$ First and second vegetation period respectively.

Most of the studies of ECM community structure have examined mature forests [10, 11, 14, 17, 41], and disturbed habitats [23, 29, 35, 42, 48], whereas relatively little is known about the species composition of ECM fungi in nurseries [32, 38, 46, 51].

According to Read [43], ECM community structure reflects adaptation to the level of carbohydrate supply from host and nutrient availability in the soil. Owing to fertilization, fumigation, and other techniques, nursery conditions differ significantly from those observed in natural ecosystems.

The aim of this study was to evaluate the diversity of ECM fungi in forest tree nurseries. We hypothesized that both edaphic factors and seedling age would affect ECM community structure. To test this hypothesis, we assessed the relative abundance of mycorrhizal morphotypes on one- and twoyear old Scots pine seedlings from four bare-root nurseries in Poland, and identified ECM fungi present on root tips using molecular methods. We used principal component analysis to estimate the association of species composition with soil nutrient content and acidity.

\section{MATERIALS AND METHODS}

\subsection{Site descriptions, plant material, and sampling procedure}

Scots pine seedlings were collected from four bare-root nurseries: Przymuszewo (P), Solec Kujawski (S), Zlotow (Z), and Okonek (O) in northwestern Poland in October and November of 2003. Standard plant production procedures were applied during preparation of plant material. Scots pine seeds were treated with fungicides (Funaben T or Oxafun $\mathrm{T}$ ) at the rate of $4 \mathrm{~g} \cdot \mathrm{kg}^{-1}$. Sowing was conducted with the single-seed seeder in rows $0.005 \mathrm{~m}$ apart, with spacing in a row $0.037 \mathrm{~m}$ in April 2001 and 2002 (two-years-old and one-year-old seedlings respectively). Soils in which seedlings were grown in all studied nurseries are fine sandy loam with poorly developed horizons and low organic matter content. Management practices, such as fertilization and fungicide applications, differed among nurseries due to differences in site conditions, site history, and response to soil properties and pathogen infections (Tab. I). Prior to the study, one-year-old (1-yr) and two-year-old (2-yr) seedlings were grown in standard nursery compartments (approximately $1 \mathrm{ha}$ ), for 17-18 months and 31-32 months, respectively. From each nursery five randomly selected samples composed of 3-5 seedlings from each age-class compartment were carefully excavated along with surrounding soil, packed in plastic bags, transported to the laboratory, and stored at $4{ }^{\circ} \mathrm{C}$ until further processing (no longer than 6 weeks). Sampling was avoided within $5 \mathrm{~m}$ of a compartment edge to avoid edge effects. A total of 40 samples (120 seedlings) from eight compartments (four nurseries $\times$ two age classes) were analyzed. In addition, three soil cores from each examined compartment were thoroughly mixed, sieved, dried and sent to the Department of Forest Soil Science of Agricultural University of Poznań Soil for chemical analyses. Total $\mathrm{N}$ and $\mathrm{C}$ contents were measured using Elemental Combustion System CHNS-O (Constech Analytical Technologies Inc., Valencia, USA). Available $\mathrm{P}_{2} \mathrm{O}_{5}$ was extracted with an acidic ammonium fluoride and the content was determined by spectrophotometry.

\subsection{Mycorrhizal evaluation}

Root systems of three seedlings from each sample were rinsed on a sieve under cold water in order to remove soil particles. Lateral roots were excised from the main root, cut into 5 -cm fragments, and mixed in a container filled with distilled water. Twenty to 25 randomly selected fragments were examined per sample. Observations of root samples were conducted under a dissecting microscope at $10 \times$ to $60 \times$ magnification. All fine roots were examined for mycorrhizal colonization. Ectomycorrhizas were separated into morphotypes based on ramification system, color and appearance of the mantle, presence of extramatrical mycelium, rhizomorphs, and other structures (cystidia, sclerotia). Preliminary identification of morphotypes was made by comparisons with available descriptions $[2,22,52]$. One out of 50 fine roots belonging to a morphotype presumed to be ectendomycorrhizal (EECM) was cross-sectioned, stained with $0.05 \%$ tryptan blue, and examined under a microscope $(400 \times)$ to verify intracellular colonization. The numbers of live mycorrhizas of each morphotype and dead fine roots were recorded. The relative abundance of each morphotype (number of root tips of each morphotype/total number of fine roots) was calculated separately for each sample. Representative subsamples (30-45 mycorrhizal systems) of each morphotype from each 
Table II. Soil characteristics for each sampled compartment from the examined forest tree nurseries in Poland (P - Przymuszewo, S - Solec Kujawski, Z - Zlotow, O - Okonek), values are means $\pm \mathrm{SD}(n=3)$.

\begin{tabular}{|c|c|c|c|c|c|c|c|c|}
\hline \multirow{2}{*}{ Soil parameter } & \multicolumn{8}{|c|}{ Nursery/age class } \\
\hline & P 1-yr & P 2-yr & S 1-yr & S 2-yr & Z 1-yr & Z 2-yr & O 1-yr & $\mathrm{O} 2-\mathrm{yr}$ \\
\hline \multirow{2}{*}{ Soil pH } & $5.55 \mathrm{~b}^{*}$ & $5.7 \mathrm{~b}$ & $6.4 \mathrm{~cd}$ & $5.85 \mathrm{bc}$ & $4.39 \mathrm{a}$ & $4.31 \mathrm{a}$ & $6.3 \mathrm{~d}$ & $6.5 \mathrm{~d}$ \\
\hline & \pm 0.11 & \pm 0.14 & \pm 0.32 & \pm 0.27 & \pm 0.21 & \pm 0.16 & \pm 0.17 & \pm 0.14 \\
\hline \multirow{2}{*}{$\% \mathrm{C}$} & $5.08 \mathrm{c}$ & $5.08 \mathrm{c}$ & $7.67 \mathrm{~d}$ & $5.04 \mathrm{c}$ & $2.65 \mathrm{~b}$ & $1.99 \mathrm{a}$ & $1.74 \mathrm{a}$ & $1.81 \mathrm{a}$ \\
\hline & \pm 0.28 & \pm 0.22 & \pm 0.31 & \pm 0.24 & \pm 0.19 & \pm 0.25 & \pm 0.27 & \pm 0.22 \\
\hline \multirow{2}{*}{$\% \mathrm{~N}$} & $0.27 \mathrm{~d}$ & $0.27 \mathrm{~d}$ & $0.46 \mathrm{f}$ & $0.32 \mathrm{e}$ & $0.20 \mathrm{c}$ & $0.15 \mathrm{~b}$ & $0.11 \mathrm{a}$ & $0.10 \mathrm{a}$ \\
\hline & \pm 0.01 & \pm 0.02 & \pm 0.03 & \pm 0.03 & \pm 0.01 & \pm 0.02 & \pm 0.01 & \pm 0.02 \\
\hline \multirow{2}{*}{$\mathrm{C} / \mathrm{N}$ ratio } & $18.9 \mathrm{~d}$ & $19 \mathrm{~d}$ & $16.9 \mathrm{c}$ & $15.6 \mathrm{~b}$ & $13.1 \mathrm{a}$ & $12.9 \mathrm{a}$ & $16.1 \mathrm{bc}$ & $17.1 \mathrm{c}$ \\
\hline & \pm 0.5 & \pm 0.3 & \pm 0.4 & \pm 0.4 & \pm 0.4 & \pm 0.5 & \pm 0.4 & \pm 0.2 \\
\hline \multirow{2}{*}{$\% \mathrm{P}_{2} \mathrm{O}_{5}$} & $9.9 \mathrm{~b}$ & $7.8 \mathrm{a}$ & $18.3 \mathrm{~d}$ & $7.3 \mathrm{a}$ & $12.3 \mathrm{c}$ & $11.5 \mathrm{c}$ & $11.7 \mathrm{c}$ & $12.3 \mathrm{c}$ \\
\hline & \pm 0.35 & \pm 0.36 & \pm 0.38 & \pm 0.32 & \pm 0.39 & \pm 0.4 & \pm 0.34 & \pm 0.36 \\
\hline
\end{tabular}

${ }^{*}$ Letters indicate significant differences between compartments at $p<0.05$ (Tukey's test).

compartment were photographed and stored at $-20^{\circ} \mathrm{C}$ for subsequent molecular identification.

\subsection{Identification of mycorrhizal species present on fine roots}

Ectomycorrhizal fungi present on fine roots were identified using RFLP (restriction fragment length polymorphism) of the ITS (internal transcribed spacer) of fungal rDNA and amplified with PCR (polymerase chain reaction). A standard pair of primers ITS1/ITS4, described by White et al. [53], was used to amplify the ITS region. The fungal DNA extraction method followed those of White et al. [53] and Gardes et al. [18] with minor modifications. Each sample consisted of a single mycorrhizal tip. The PCR protocol followed that of Kåren et al. [30]. To optimize PCR amplification 1:10, 1:20, and 1:40 dilutions of extracted templates were tested before the sample was presumed to be not amplified. Controls with ultra pure water were run to check for contamination. The amplified product was digested with three enzymes: Hinf I, Mbo I, and Taq I (Eurx). Restriction fragments were separated using $2 \%$ agarose gel electrophoresis $(10 \mathrm{~V} / \mathrm{cm})$, stained with $0.5 \%$ ethidium bromide, and recorded on black and white Polaroid ${ }^{\mathrm{TM}}$ film. Morphotypes were identified by comparing RFLP patterns of the ITS with reference RFLP patterns obtained from a regional collection of sporocarps and isolates of EECM fungi using the Taxotron ${ }^{\circledR}$ software package (Pasteur Institute, Paris, France). Samples of unidentified RFLP types and representatives of suilloid RFLP patterns were sequenced with ITS1/4 primers in the Laboratory of Molecular Biology of Adam Mickiewicz University and compared with available sequences from GenBank using Blastn.

\subsection{Data analysis}

The diversity of the ectomycorrhizas on the seedlings was expressed as the number of identified ECM species (species richness). The relative abundance of individual ECM fungal species was calculated as a proportion of the total number of ectomycorrhizal roots averaged over each sample. One way analysis of variance with Tukey's test was used to compare the soil parameters, degree of mycorrhizal colonization, the extent of ECM and EECM colonization and relative abundances of mycorrhizal species between nurseries and age classes. Principle Components Analysis (PCA) was used to analyze the relationship between the mycorrhizal relative abundance of ECM fungal species and tested variables (soil parameters and age of seedlings). Relative abundance values were transformed $\left(\log _{10}+1\right)$ before analysis, and the PCA was performed with CANOCO 4.51 software.

\section{RESULTS}

\subsection{Soil factors}

Soil properties of all examined nurseries and age classes are summarized in Table II. The measured soil factors ( $\mathrm{pH}, \mathrm{C}, \mathrm{N}$ and $\mathrm{P}$ contents, $\mathrm{C} / \mathrm{N}$ ratio,) exhibited a high degree of variation among the examined nurseries and age classes. The $\mathrm{pH}\left(\mathrm{H}_{2} \mathrm{O}\right)$ was highest in Okonek (O 1-yr, O 2-yr) and Solec Kujawski nurseries (S 1-yr), intermediate in Solec Kujawski (S 2-yr) and Przymuszewo (P 1-yr and P 2-yr) nurseries, and lowest in the Zlotow nursery ( $\mathrm{Z} 1-\mathrm{yr}, \mathrm{Z} 2-\mathrm{yr})(p=0.05)$. C, $\mathrm{N}$ and $\mathrm{P}$ contents were highest in $\mathrm{S} 1-\mathrm{yr}$ reaching $7.67 \%, 0.46 \%$ and $18.3 \%$ respectively, whereas lowest values of $\mathrm{C}$ and $\mathrm{N}$ contents occurred in $\mathrm{O}$ nursery on both age classes $(1.74 \% \mathrm{C}, 0.10 \% \mathrm{~N})$ and lowest P content in S 2-yr (7.3\%).

\subsection{Mycorrhizal root colonization of ectomycorrhizal (ECM) and ectendomycorrhizal (EECM) fungi}

Overall values of mycorrhizal colonization were high in each nursery and age class, with little variation among seedlings of the different nurseries and age classes (Fig. 1a). Colonization was significantly lower than all other nurseries and age classes $(p=0.05)$ only in the Okonek nursery on twoyear-old seedlings (O 2-yr). Mean colonization of seedlings was $78.6 \%$, ranging from $67.8 \%$ in the $\mathrm{O} 2$-yr compartment to $90.6 \%$ in the P 2-yr compartment. 

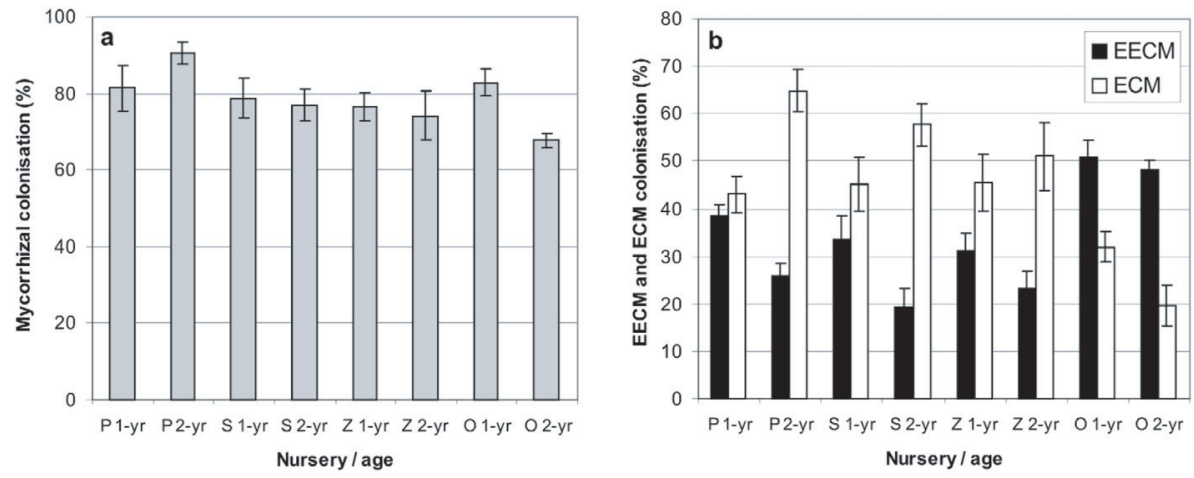

Figure 1. Mean values and standard deviations of (a) overall mycorrhizal colonization and (b) relative abundance of ectendo-, and ectomycorrhizas of 1-, and 2-year-old Scots pine seedlings from four nurseries: P: Przymuszewo; S: Solec Kujawski; Z: Zlotow; O: Okonek.

EECM colonization was significantly greater than ECM colonization only in O nursery, in all other nurseries ECM colonization surpassed EECM colonization, nevertheless not significantly in P 1-yr (Fig. 1b). The relative abundance of ectomycorrhizas increased with seedling age from approximately $45 \%$ in one-year- old seedlings to $64 \%, 58 \%$, and $51 \%$ in twoyear-old seedlings in the $\mathrm{P}, \mathrm{S}$, and $\mathrm{Z}$ nurseries, respectively, however, the differences were statistically significant only for the $\mathrm{P}(p=0.0014)$ and $\mathrm{S}(p=0.009)$ nurseries. The relative abundance of ECM in the $\mathrm{O}$ nursery was considerably lower than in the remaining nurseries $(p<0.03)$ and decreased with seedling age from $32 \%$ to $20 \%$. In contrast, the highest EECM colonization occurred in the $\mathrm{O}$ nursery $(50 \%$ on both one- and two-year-old seedlings). Mean EECM colonization in the P, S, and $\mathrm{Z}$ nurseries was $34 \%$ in one-year-old seedlings and $23 \%$ in two-year-old seedlings with the lowest value in the S 2-yr compartment (19\%).

\subsection{Morphotype assessment}

Morphological assessment was carried out on approximately 8000 mycorrhizas from 120 seedlings. Based on gross morphology, eight mycorrhizal morphotypes were distinguished (listed and described in Tab. III). We found seven morphotypes in the Z nursery, six in $\mathrm{P}$, four morphotypes in $\mathrm{S}$, and only two in the O nursery.

The most common morphotypes, EECM and Tter, were present in each examined nursery and seedling age class. Despite a decreased abundance with increased seedling age, they dominated and comprised on average $38 \%$ and $25 \%$ of the root tips of the one-year-old seedlings, whereas on two-year-old seedlings they occurred on $27 \%$ and $13 \%$ of the roots (pooled data from four nurseries). Two morphotypes belonging to the suilloid group (suilloid white - SW, and suilloid pink - SP) were present on seedlings from the $\mathrm{P}, \mathrm{S}$, and $\mathrm{Z}$ nurseries. Their relative abundance was significantly higher on two-year than one-year-old seedlings. The suilloid brown morphotype (SB) was found on root systems of seedlings from the $\mathrm{P}$ nursery. The Hebeloma-type morphotype (Heb) was present in the $\mathrm{P}$ and $\mathrm{Z}$ nurseries, but its relative abundance was much greater in the $\mathrm{Z}$ nursery on both one- and two-year-old seedlings
(3\% P 1-yr; 7\% P 2-yr; 20\% Z 1-yr; 22\% Z 2-yr). Tub and Black morphotypes were detected only in the $\mathrm{Z}$ nursery on two-years-old seedlings at low relative abundances at $0.5 \%$ for Tub and $6 \%$ for Black.

\subsection{Molecular identification}

In total, 228 out of 352 mycorrhizal tips representing all morphotypes, yielded PCR product and was subjected to ITS-RFLP analysis. Overall successful amplification rate reached $65 \%$. Root tips from the suilloid group (morphotypes SW, SP, and SB) were the most difficult to amplify (54\%)

Most of the morphotypes in this study consisted of more than one RFLP type. The RFLP types identified as Suillus species were detected in more than one morphotype (Tab. IV). Since the suilloid morphotypes turned out to be species mixtures of three Suillus and two Rhizopogon species, we decided to treat this group in quantitative estimations as a combined suilloid group. We are cautious of drawing conclusions concerning the relative abundances of suilloid species in the $\mathrm{P}$ and $S$ nurseries based on the frequency of suilloid RLFP patterns obtained from mycorrhizas, because the successful amplification rate was quite variable between the suilloid morphotypes and samples, indicating a possible bias in the estimations (Tab. IV).

We obtained 13 distinct RFLP patterns, nine of which were matched with our reference data bank containing 94 fungal taxa. The RFLP type $P$. fortinii-like was very similar to the RFLP pattern of the Phialocephala fortinii isolate, but the $120 \mathrm{bp}$ band in the TaqI digestion was missing. This might be explained either as an intraspecific polymorphism of the ITS sequence or a failure to detect a faint band on the gel. The remaining RFLP types were identified as Wilcoxina mikolae, Rhizopogon roseolus, and Tuber sp. by comparing the ITS sequences with GenBank accessions. The ITS sequence analysis of 12 suilloid mycorrhizas confirmed the adequacy of the RFLP typing (97-99\% homology with reference sequences from GenBank). 
Table III. Description of mycorrhizal morphotypes.

\begin{tabular}{|c|c|c|}
\hline Morphotype & Description & Site $^{\mathrm{a}}$ \\
\hline$\overline{\text { EECM }}$ & $\begin{array}{l}\text { Ectendomycorrhizal, light to dark brown, with pale tip, single or dichotomously branched, } \\
\text { fairly long, thin, reticulate, and shiny mantle, extramatrical hyphae (EMH) and strands absent, } \\
\text { Wilcoxina mikolae-type }\end{array}$ & All \\
\hline Black & $\begin{array}{l}\text { Single mycorrhizas, black, shiny mantle, often as a compact patch, loose black hyphae ex- } \\
\text { tending towards the pale tip, in Ingleby et al. [22] described as ITE.3, Phialocephala fortinii } \\
\text { in [28] }\end{array}$ & Z 2-yr \\
\hline Tub & $\begin{array}{l}\text { Orange, single, club-shaped mycorrhizas with a smooth mantle texture and small cystydia em- } \\
\text { anating from mantle, EMH and rhizomorphs absent, Tuber-type [52] }\end{array}$ & Z 2-yr \\
\hline Tter & $\begin{array}{l}\text { Yellow-brown to dark brown, single, dichotomously or irregularly branched, smooth, thick } \\
\text { mantle, cystydia infrequently found, EMH sparse or absent; Thelephora terrestris-type }\end{array}$ & All \\
\hline SW & $\begin{array}{l}\text { Suilloid - white, single to coralloid, white, thick, gelatinous mantle, abundant fluffy EMH, col- } \\
\text { ored as the mantle, differentiated and interconnected strands, also white, soil particles closely } \\
\text { associated with mycorrhizas }\end{array}$ & $\begin{array}{l}\text { All except } \\
\text { O 1-yr, O 2-yr }\end{array}$ \\
\hline SP & $\begin{array}{l}\text { Suilloid - pink, dichotomous or cluster-forming mycorrhizas, thick, pink mantle, EMH and } \\
\text { differentiated strands present, concolorous with mantle }\end{array}$ & $\begin{array}{l}\text { All except } \\
\text { O 1-yr,O 2-yr }\end{array}$ \\
\hline SB & $\begin{array}{l}\text { Suilloid - brown, dichotomously branched, light brown mycorrhizal systems, at the base cov- } \\
\text { ered by white, abundant EMH, strands brown }\end{array}$ & P 1-yr, P 2-yr \\
\hline Heb & $\begin{array}{l}\text { Long, dichotomous mycorrhizas, white to light brown, patchy mantle, covered by cottony } \\
\text { EMH, strands absent, Hebeloma - type }\end{array}$ & $\begin{array}{l}\text { P 1-yr, P 2-yr } \\
\text { Z 1yr, Z 2-yr }\end{array}$ \\
\hline
\end{tabular}

${ }^{a}$ Refers to nurseries and seedling age classes were the morphotype was observed, P - Przymuszewo, Z- Zlotow, O - Okonek nursery.

\subsection{Mycorrhizal community composition}

The highest diversity of mycorrhizal fungi was found in nursery $\mathrm{P}$ (eight species) and $\mathrm{Z}$ (seven species), intermediate levels in nursery $S$ (five species) and the lowest diversity in nursery $\mathrm{O}$ (two species) (Tab. V). No differences in species richness between the two age classes were detected in the $\mathrm{P}, \mathrm{S}$, and $\mathrm{O}$ nurseries, whereas in the $\mathrm{Z}$ nursery, three additional species (Tricharina ochroleuca, Phialocephala fortinii, and Tuber sp.) were identified on two-year- old compared to one-year-old seedlings. Since these species were present at low abundances in the community ( $6 \%$ in Z 2-yr), we conclude that at least in nursery conditions, seedling age has a negligible influence on qualitative community structure.

The most common and abundant mycorrhizal symbionts were Wilcoxina mikolae and Thelephora terrestris, which were both present in each examined nursery and seedling age class. The relative abundances of these species generally decreased with seedling age from approximately $63 \%$ on one-year old seedlings to $40 \%$ in rootlets of two-year old seedlings (data pooled for both species and all nurseries; $r^{2}=0.35, p<$ 0.0001, for details see Tab. V).

The group of suilloid fungi had the richest representation in the P nursery where three Suillus and two Rhizopogon species were present in both seedling age classes. Among the nurseries, $S$. variegatus was the most frequent and was detected on seedlings from the $\mathrm{P}, \mathrm{S}$, and $\mathrm{Z}$ nurseries. R. luteolus and
$R$. roseolus occurred only in the $\mathrm{P}$ and $\mathrm{S}$ nurseries, whereas $S$. bovinus and $S$. luteus were present only in the P nursery. The relative abundance of the suilloid group increases with seedling age from $12 \%$ to $40 \%$ in nursery $\mathrm{P}$, from $18 \%$ to $41 \%$ in S, and from $14 \%$ to $26 \%$ in Z. Tukey's test indicates that seedling age class had a significant effect on the abundance of the suilloid group in these nurseries $(p<0.001$ for $\mathrm{P}$ and $\mathrm{S}$; $p=0.0117$ for $\mathrm{Z}$ ).

Likewise for $H$. crustuliniforme in nursery $\mathrm{P}$, we found a small, but significant $(p=0.009)$ increase in colonization with age class (3\% in $\mathrm{P} 1-\mathrm{yr} ; 7 \%$ in $\mathrm{P} 2-\mathrm{yr}$ ), whereas $H$. longicaudum in nursery $\mathrm{Z}$ had similar colonization percentages in both age classes (20\% in Z 1-yr; 22\% in Z 2-yr).

Principal component analysis (PCA) based on pooled data from all examined nurseries revealed a lack of apparent correlations between the relative abundances of species (or species group in case of the suilloid taxa) and edaphic factors (Fig. 2) with the exception of a weak correlation between $T$. terrestris abundance and soil $\mathrm{pH}\left(r^{2}=0.519 ; p=0.0436\right)$.

\section{DISCUSSION}

Molecular approaches (RFLP and sequencing of rDNA ITS) combined with classical methods, such as morphotyping, enabled reliable assessment of fungal species richness and allowed us to track morphological variability 
Table IV. Molecular identification with morphotype assignment of mycorrhizas, total number of mycorrhizas identified by ITS-RFLP, and total number of RFLP-taxa identified for each nursery and age class.

\begin{tabular}{|c|c|c|c|c|c|c|c|c|c|}
\hline \multirow{3}{*}{ Species / RFLP type } & \multirow{3}{*}{ Morphotype } & \multicolumn{8}{|c|}{ No. of root tips with specific RFLP pattern } \\
\hline & & \multicolumn{2}{|c|}{ Przymuszewo } & \multicolumn{2}{|c|}{ Solec Kujawski } & \multicolumn{2}{|c|}{ Zlotow } & \multicolumn{2}{|c|}{ Okonek } \\
\hline & & P-1yr & $\mathrm{P}-2 \mathrm{yr}$ & S-1yr & $\mathrm{S}-2 \mathrm{yr}$ & Z-1yr & $\mathrm{Z}-2 \mathrm{yr}$ & $0-1 \mathrm{yr}$ & $0-2 \mathrm{yr}$ \\
\hline Wilcoxina mikolae & $\mathrm{EECM}^{\mathrm{b}}$ & 9 & 13 & 6 & 16 & 4 & 4 & & \\
\hline Wilcoxina mikolae RFLP type II* & EECM & & & & & & & 6 & 5 \\
\hline Thelephora terrestris & Tter & 5 & 8 & 4 & 9 & 3 & 4 & 3 & 4 \\
\hline Suillus variegatus ${ }^{\mathrm{a}}$ & $\mathrm{SW}^{\mathrm{b}}, \mathrm{SP}^{\mathrm{b}}$ & 4 & 10 & 14 & 13 & 5 & 7 & & \\
\hline Suillus bovinus ${ }^{\mathrm{a}}$ & SW, SP & 4 & 7 & & & & & & \\
\hline Suillus luteus ${ }^{\mathrm{a}}$ & SW, SP, SB & 5 & 12 & & & & & & \\
\hline Rhizopogon luteolus* & SP & 3 & 6 & 3 & 5 & & & & \\
\hline Rhizopogon roseolus & SW & 1 & 2 & 2 & 2 & & & & \\
\hline Hebeloma crustuliniforme & $\mathrm{Heb}^{\mathrm{b}}$ & 2 & 3 & & & & & & \\
\hline Hebeloma longicaudum & Heb & & & & & 4 & 6 & & \\
\hline Tricharina ochroleuca & Black $^{\mathrm{b}}$ & & & & & & 2 & & \\
\hline Phialocephala fortinii-like & Black & & & & & & 1 & & \\
\hline Tuber sp.* & Tub & & & & & & 1 & & \\
\hline $\begin{array}{l}\text { No. of mycorrhizal tips used in } \\
\text { ITS-RFLP }\end{array}$ & & 48 & 96 & 48 & 72 & 24 & 32 & 12 & 12 \\
\hline Unamplified & & 15 & 36 & 19 & 27 & 8 & 7 & 3 & 3 \\
\hline Total no. of RFLP types & & 8 & 8 & 5 & 5 & 4 & 7 & 2 & 2 \\
\hline
\end{tabular}

${ }^{a}$ RFLP type found in more than one morphotype, ${ }^{b}$ morphotype with more than one RFLP pattern, ${ }^{*}$ RFLP type identified by ITS sequence analysis of ITS.

Table V. Relative abundance of mycorrhizal species on roots of Scots pine seedlings from forest tree nurseries, counted as a percent of the total number of fine roots, standard deviations in parentheses $(n=5)$.

\begin{tabular}{llllccccc}
\hline $\begin{array}{l}\text { Nursery/ } \\
\text { age class }\end{array}$ & $\begin{array}{l}\text { Wilcoxina } \\
\text { mikolae }\end{array}$ & $\begin{array}{l}\text { Thelephora } \\
\text { terrestris }\end{array}$ & Suilloid group* & $\begin{array}{c}\text { Hebeloma } \\
\text { crustuliniforme }\end{array}$ & $\begin{array}{c}\text { Hebeloma } \\
\text { longicaudum }\end{array}$ & $\begin{array}{c}\text { Tricharina } \\
\text { ochroleuca }\end{array}$ & $\begin{array}{c}\text { Tuber sp. } \\
\text { Phialocephala } \\
\text { fortinii-like }\end{array}$ & $\begin{array}{c}\text { Species } \\
\text { richness }\end{array}$ \\
\hline P 1-yr & $38.4( \pm 2.4)$ & $27.8( \pm 2.7)$ & $12.4( \pm 2.4) ; 5^{\text {a }}$ & $2.8( \pm 1.9)$ & - & - & - & - \\
P 2-yr & $25.8( \pm 2.2)$ & $9.0( \pm 1.6)$ & $49.0( \pm 4.9) ; 5$ & $6.8( \pm 4.1)$ & - & - & - & - \\
S 1-yr & $33.6( \pm 3.9)$ & $26.8( \pm 3.5)$ & $18.4( \pm 4.2) ; 3$ & - & - & - & - & - \\
S 2-yr & $19.2( \pm 3.3)$ & $16.6( \pm 2.4)$ & $41.0( \pm 4.9) ; 3$ & - & - & - & - & - \\
Z 1-yr & $31.2( \pm 3.5)$ & $12.0( \pm 3)$ & $13.6( \pm 2.0) ; 1$ & - & $19.8( \pm 2.7)$ & - & - & - \\
Z 2-yr & $16.8( \pm 2.7)$ & $7.0( \pm 2.1)$ & $21.6( \pm 3.2) ; 1$ & - & $22.4( \pm 3.2)$ & 4 & 0.5 & 2 \\
O 1-yr & $50.8( \pm 3.7)$ & $32.0( \pm 3.2)$ & - & - & - & - & - & 7 \\
O 2-yr & $48.2( \pm 4.4)$ & $19.6( \pm 4.2)$ & - & - & - & - & - & 2 \\
\hline
\end{tabular}

* Suillus and Rhizopogon spp. treated as a combined group, ${ }^{\text {a }}$ indicates number of suilloid species.

amongst mycorrhizas formed by individual fungal species. The number of RFLP types was greater than the number of morphotypes recorded (13 vs. 8). Three of the morphotypes corresponded well with specific RFLP patterns, whereas five other morphotypes consisted of more than one RFLP type. On the other hand, specific RFLP types could be found in mycorrhizas assigned to different morphotypes. All three Suillus species were detected in at least two morphotypes (Tab. IV). Although the SB morphotype showed a distinct RFLP type in this study, our ongoing study of young Scots pine plantations revealed that this suilloid morphotype might also consist of several suilloid species (unpublished). This type of intermingled correlations between morphotypes and RFLP types has been reported previously $[13,30]$.

Our investigation revealed high morphological variability of mycorrhizas formed by suilloid species. This fact, together with inconsistent amplification rates of their ITS, prevented us from an assessment of their exact abundances in nurseries. Since all three morphotypes classified as "suilloid" turned out to be Suillus or Rhizopogon species, we believe that despite apparent differences, classifying the suilloid mycorrhizas as a single morphotype would be a more appropriate approach in future research. The morphological variability of suilloid fungi might be attributed to phenotypic variation of individuals and differences in environmental conditions (Mleczko, pers. comm.). Conversely, a close evolutionary relationship between the Suillus and Rhizopogon genera [19] probably contribute to the resemblance of mycorrhizas formed by different suilloid species.

Two RFLP types were found within the one EECM morphotype, both identified as W. mikolae, either by RFLP typing (P, S, Z nurseries) or sequencing of ITS region (unknown 


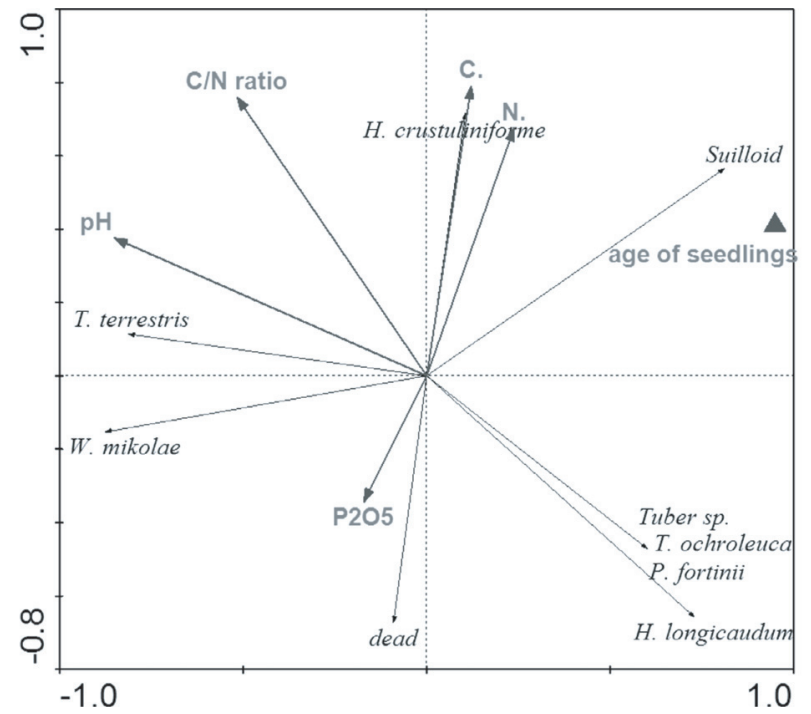

Figure 2. Principal component analysis (PCA) of ECM community structure in forest tree nurseries. Eigenvalues for the first and second axis are 0.53 and 0.338 , respectively.

RFLP type 1 from the $O$ nursery). Intraspecific polymorphisms of ITS sequence have been previously reported for many mycorrhizal fungi $[20,30]$, including $W$. rehmii $[16]$ and unidentified morphotype described as an E-strain [36].

The species richness in the examined nurseries varied between two and eight fungal taxa on both seedling age classes (Tab. V). Similar results were obtained in other surveys of mycorrhizal communities in forest nurseries. On the basis of morphological and anatomical methods, Ursic et al. [51] characterized six mycorrhizal species present on two- and threeyear-old Pinus strobus seedlings from a bare-root nursery. In a broad survey of the mycorrhizal status of Scots pine seedlings in Polish nurseries, Rudawska et al. [46] found between one and nine mycorrhizal types per nursery, whereas four to nine mycorrhizal taxa were identified on Picea glauca seedlings from four containerized seedling nurseries [32]. Similarly, Menkis et al. [38] found nine mycorrhizal species colonizing Scots pine seedlings in bare-root nurseries.

As shown previously, seedlings growing under the canopy of mature trees or in close proximity to a mature forest seem to maintain a higher diversity of mycorrhizal fungi. Jonsson et al. [25] demonstrate that the ectomycorrhizal species composition of self-regenerating Scots pine seedlings (1 to 10 year-old cohorts) in a forest is similar to that of surrounding trees and is comprised of 16-21 fungal taxa. Kranabetter and Wylie [34] found an ECM species richness gradient on naturally regenerated western hemlock seedlings in forest openings, ranging from 13.1 morphotypes under the canopy to 7.8 in 15 m gap positions. Similarly, a comparison of ECM communities of young $P$. muricata seedlings after a standreplacing fire in shrub and forest sites showed marked differences in species richness ( 3 and 13 ECM species, respectively) [21].
The discrepancy between ECM species richness and composition of even-aged seedlings growing in nurseries (likewise in settings where no mature trees are present) and under the canopy of trees might be explained in terms of different life history strategies of ECM species. It seems that fungal species richness at the tree seedling stage is a function of the inoculum potential of different fungal species and their ability to colonize roots from spores [50]. ECM species which disperse effectively via resistant propagules would appear first in disturbed habitats and nurseries, whereas those species which colonize host roots mainly through growth of the extramatrical mycelium (EM) would be unable to persist, but would occur under a forest canopy. In mature forest stands, a carbohydrate supply from established trees might facilitate ECM colonization of young seedlings [25]. The roots of seedlings are incorporated into an established mycelial network connected to mycorrhizas of trees, and consequently fungi with higher carbohydrate demands (so-called "late-stage" fungi) may colonize seedlings.

Most of the ECM fungi identified on Scots pine seedlings in the examined nurseries are typical colonizers of nurserygrown conifers. W. mikolae and T. terrestris have been reported repeatedly on nursery seedlings $[22,32,38,51,52]$ and are known for their ubiquitous nature. They appear to be pioneer or ruderal fungi with low host specificity, a short vegetation phase, and high dispersal rate [6]. Due to low competitiveness their abundance after outplanting typically decreases with time. Similarly, Hebeloma spp. are classified as pioneer species, occurring in young forest plantations with a low humus content and in disturbed habitats [37]. The abundant occurrence of suilloid fungi, especially Rhizopogon spp. might be attributed to the evenness of spore distribution in a variety of habitats, longevity of spores [33], and spore resistance to abiotic factors. Rincón et al. [45] showed that Rhizopogon spp. are efficient colonizers of Pinus pinea seedlings and significantly increase $\mathrm{N}$ and $\mathrm{P}$ concentrations of inoculated plants. Also performance and survival of the Pinus pinea seedlings outplanted in formerly arable land, is improved after inoculation with Rhizopogon spp., suggesting their considerable competitive abilities [40] The ability of Suillus species to colonize seedlings in laboratory conditions and in inoculation experiments is well documented [47]. Suillus species occur in nurseries $[8,31,39]$ and on naturally regenerating seedlings $[21,25]$. Three ascomycetes occurred in the $\mathrm{Z}$ nursery, namely $T$. ochroleuca, Tuber sp., and P. fortinii. Phialocephala fortinii, a dark-septate fungus, is a reported associate of pines at early successional stages $[25,27]$. The mycorrhizal status of this species is unclear, although it forms inter- and intracellular exchange interfaces in roots, it can be mutualistic, neutral, or pathogenic under different conditions and with different host species [26]. As was demonstrated by Jumpponen et al. [27], P. fortinii significantly improved $\mathrm{P}$ uptake and growth of Pinus contorta seedlings and increased $\mathrm{N}$ uptake and total seedling biomass when $\mathrm{N}$ was added. In light of the fact that $\mathrm{N}$ amendments are a common nursery practice, it is likely that $P$. fortinii is beneficial for pine seedlings in nursery conditions. 
Acknowledgements: We thank Dr Mark Tjoelker for critical reading of the manuscript and English correction and Dr Marek Kasprowicz for statistical advice. We also wish to thank two anonymous reviewers for helpful comments on this study.

\section{REFERENCES}

[1] Abuzindah R.A., Read D.J., The role of proteins in the nitrogen nutrition of ectomycorrhizal plants. I. utilization of peptides and proteins by ectomycorrhizal fungi, New Phytol. 103 (1986) 481493.

[2] Agarer R., Colour atlas of ectomycorrhizae, Einhorn-Verlag, Schwäbisch Gmünd, Germany, 1987-1996.

[3] Bruns T.D., Bidartondo M.I., Taylor D.L., Host specifity in ectomycorrhizal communities: what do the exceptions tell us? Integ. Comp. Biol. 42 (2002) 352-359.

[4] Buscot F., Munch J.C., Charcosset J.Y., Gardes M., Nehls U., Hampp R., Recent advances in exploring physiology and biodiversity of Ectomycorrhizas highlight the functioning of these symbioses in ecosystems, FEMS Microbiol. Rev. 24 (2000) 601-614.

[5] Cairney J.W.G., Intraspecific physiological variation: implications for understanding functional diversity in ectomycorrhizal fungi, Mycorrhiza 9 (1999) 125-135.

[6] Colpaert J.V., Thelephora, in: Cairney J.W.G., Chambers S.M. (Eds.) Ectomycorrhizal fungi: key genera in profile, SpringerVerlag Berlin Heidelberg, 1999, pp. 325-246.

[7] Dahlberg A., Effect of soil humus cover on the establishment and development of mycorrhizae on containerized Pinus sylvestris $\mathrm{L}$. and Pinus contorta ssp. latifolia Engelm. after outplanting, Scand. J. For. Res. 5 (1990) 103-112.

[8] Dahlberg A., Finlay R.D., Suillus, in: Cairney J.W.G., Chambers S.M. (Eds.), Ectomycorrhizal fungi: key genera in profile, SpringerVerlag Berlin Heidelberg, 1999, pp. 33-64.

[9] Dahlberg A., Stenström E., Dynamic changes in nursery and indigenous mycorrhiza of Pinus sylvestris seedlings planted out in forest and clearcuts, Plant Soil 136 (1991) 73-86.

[10] Dahlberg A., Jonsson L., Nylund J.-E., Species diversity and distribution of biomass above and below ground among ectomycorrhizal fungi in an old-growth Norway spruce forest in south Sweden, Can. J. Bot. 75 (1997) 1323-1335.

[11] Dickie I.A., Reich P.B., Ectomycorrhizal fungal communities at forest edges, J. Ecol. 93 (2005) 244-255.

[12] Duchesne L.C., Role of ectomycorrhizal fungi in biocontrol, in: Pfleger F.L. Linderman R.G. (Eds.), Mycorrhizae in plant health, APS Press, St. Paul, Minn., 1994, pp. 27-45.

[13] Erland S., Taylor A.F.S., Diversity of ecto-mycorrhizal fungal communities in relation to the abiotic factors, in: van der Heijden M.G.A., Sanders I. (Eds.), Mycorrhizal ecology, Springer-Verlag Berlin Heidelberg, 2002, pp. 163-195.

[14] Erland S., Jonsson T., Mahmood S., Finlay R.D., Below-ground ectomycorrhizal community structure in two Picea abies forest in southern Sweden, Scand. J. For. Res. 14 (1999) 209-217.

[15] Fleming L.V. Effects of soil trenching and coring on the formation of ectomycorrhizas on birch seedlings grown around mature trees, New Phytol. 98 (1983) pp. 143-153.

[16] Fujimara K.E., Smith J.E., Horton T.R., Weber N.S., Spatafora J.W., Pezizalean mycorrhizas and sporocarps in ponderosa pine (Pinus ponderosa) after prescribed fires in eastern Oregon, USA, Mycorrhiza 15 (2005) 79-86.

[17] Gardes M., Bruns T.D., Community structure of ectomycorrhizal fungi in a Pinus muricata forest: above- and below-ground views, Can. J. Bot. 74 (1996) 1572-1583.
[18] Gardes M., White T.J., Fortin J.A., Bruns T.D., Taylor J.W., Identification of indigenous and introduced symbiotic fungi in ectomycorrhizae by amplification of nuclear and mitochondrial ribosomal DNA, Can. J. Bot. 69 (1991) 180-190.

[19] Grubisha L.C., Trappe J.M., Molina R., Spatafora J.W., Biology of ectomycorrhizal genus Rhizopogon. VI. Re-examination of infrageneric relationships inferred from phylogenetic analyses of ITS sequences, Mycologia 94 (2002) 607-619.

[20] Horton T.R., Bruns T.D., The molecular revolution in ectomycorrhizal ecology: peeking into the black-box, Mol. Ecol. 10 (2001) 1855-1871.

[21] Horton T.R., Cázares E., Bruns T.D., Ectomycorrhizal, vesiculararbuscular and dark septate fungal colonization of bishop pine (Pinus muricata) seedlings in the first 5 months of growth after wildfire, Mycorrhiza 8 (1998) 11-18.

[22] Ingleby K., Mason P.A., Last F.T., Fleming L.V., Identification of ectomycorrhizas, HMSO, London, 1990.

[23] Jansen A.E., Dighton J., Effects of air pollutants on ectomycorrhizas, Air Pollution Research Report 30, Brussels, 1990.

[24] Jones M.D., Durall D.M., Cairney J.W.G., Ectomycorrhizal fungal communities in young forest stands regenerating after clearcut logging, New Phytol. 157 (2003) 399-422.

[25] Jonsson L., Dahlberg A., Nilsson M.-C., Kåren O., Zackrisson O., Continuity of ectomycorrhizal fungi in self-regenerating boreal Pinus sylvestris forests studied by comparing mycobiont diversity on seedlings and mature trees, New Phytol. 142 (1999) 151-162.

[26] Jumpponen A., Dark septate endophytes - are they mycorrhizal? Mycorrhiza 11 (2001) 207-211.

[27] Jumpponen A., Mattson K.G., Trappe J.M., Mycorrhizal functioning of Phialocephala fortinii with Pinus contorta on glacier forefront soil: interactions with soil nitrogen and organic matter, Mycorrhiza 7 (1998) 261-265.

[28] Kaldorf M., Renker C., Fladung M., Buscot F., Characterization and spatial distribution of ectomycorrhizas colonizing aspen clones released in an experimental field, Mycorrhiza 14 (2004) 295-306.

[29] Kåren O., Nylund J.-E., Effects of ammonium sulphate on the community structure and biomass of ectomycorrhizal fungi in a Norway spruce stand in southwestern Sweden, Can. J. Bot. 75 (1997) 16281642.

[30] Kåren O., Högberg N., Dahlberg A., Jonsson L., Nylund J.-E., Interand intraspecific variation in the ITS region of rDNA of ectomycorrhizal fungi in Fennoscandia as detected by endonuclease analysis, New Phytol. 136 (1997) 313-325.

[31] Karkouri K.E., Martin F., Douzery J.P.E., Mousain D., Diversity of ectomycorrhizal fungi naturally established on containerised Pinus seedlings in nursery conditions, Microbiol. Res. 160 (2005) 47-52.

[32] Kernaghan G., Sigler L., Khasa D., Mycorrhizal and root endophytic fungi of containerized Picea glauca seedlings assesed by rDNA sequence analysis, Microb. Ecol. 45 (2003) 128-136.

[33] Kjøller R., Bruns T.D., Rhizopogon spore bank communities within and among California pine forests, Mycologia 95 (2003) 603-613.

[34] Kranabetter J.M., Wylie T., Ectomycorrhizal community structure across forest openings on naturally regenerated western hemlock seedlings, Can. J. Bot. 76 (1998) 189-196.

[35] Lilleskov E.A., Fahey T.J., Horton T.R., Lovett G.M., Belowground ectomycorrhizal fungal community change over a nitrogen deposition gradient in Alaska, Ecology 83 (2002) 104-115.

[36] Mah K., Tackaberry L.E., Egger K.N., Massicotte H.B., The impacts of broadcast burning after clear-cutting on the diversity of ectomycorrhizal fungi associated with hybrid spruce seedlings in central British Columbia, Can J. For. Res. 31 (2001) 224-235.

[37] Marmeisse R., Guidot A., Gay G., Lambilliotte R., Sentenac H., Combier J.-P., Melayah D., Fraissinet-Tachet L., Debaud J.C., Hebeloma cylindrosporum - a model species to study ectomycorrhizal symbiosis from gene to ecosystem, New Phytol. 163 (2004) 481-498. 
[38] Menkis A., Vasiliauskas R., Taylor A.F.S., Stenlid J., Finlay R., Fungal communities in mycorrhizal roots of conifer seedlings in forest nurseries under different cultivation systems, assessed by morphotyping, direct sequencing and mycelial isolation, Mycorrhiza 16 (2005) 33-41.

[39] Molina R., Trappe J.M., Mycorrhiza management in bareroot nurseries, in: Mary L., Landis T.D. (Eds.), Forest nursery manual Production of bareroot seedlings, martinus Nijhoff/Dr W. Junk Publishers, The Hague/Boston/Lancaster, 1984, pp. 211-223.

[40] Parladé J., Luque J., Pera J., Rincón A.M., Field performance of Pinus pinea and $P$. halepensis seedlings inoculated with Rhizopogon spp. and outplanted in formerly arable land, Ann. For. Sci. 61 (2004) 507-514.

[41] Peter M., Ayer F., Egli S., Honegger R., Above- and below-ground community structure of ectomycorrhizal fungi in three Norway spruce (Picea abies) stands in Switzerland, Can. J. Bot. 79 (2001) 1134-1151.

[42] Peter M., Ayer F., Egli S., Nitrogen addition in a Norway spruce stand altered macromycete sporocarp production and below-ground ectomyccorrhizal species composition, New Phytol. 149 (2001) 311-325.

[43] Read D.J., Mycorrhizas in ecosystems, Experientia 47 (1991) 376391.

[44] Read D.J., Perez-Moreno J., Mycorrhizas and nutrient cycling in ecosystems - a journey towards relevance? New Phytol. 157 (2003) 475-492.

[45] Rincón A., Parladé J., Pera J., Effects of ectomycorrhizal inoculation and the type of substrate on mycorrhization, growth and nutrition of containerised Pinus pinea L. seedlings produced in a commercial nursery, Ann. For. Sci. 62 (2005) 817-822.
[46] Rudawska M., Leski T., Gornowicz R., Mycorrhizal status of Pinus sylvestris L. nursery stock in Poland as influenced by nitrogen fertilization, Dendrobiology 46 (2001) 49-58.

[47] Smith S.E., Read D.J., Mycorrhizal symbiosis, 2nd ed., San Diego, CA, USA Academic Press, 1997.

[48] Stendell E.R., Horton T.R., Bruns T.D., Early effects of prescribed fire on the structure of the ectomycorrhizal fungus community in a Sierra Nevada ponderosa pine forest, Mycol. Res. 103 (1999) 13531359

[49] Stenström E., Ek M., Field growth of Pinus sylvestris following nursery inoculation with mycorrhizal fungi, Can. J. For. Res. 20 (1990) 914-918.

[50] Taylor D.L., Bruns T.D., Community structure of ectomycorrhizal fungi in a Pinus muricata forest: minimal overlap between the mature forest and resistant propagules communities, Mol. Ecol. 8 (1999) 1837-1850.

[51] Ursic M., Peterson R.L., Husband B., Relative abundance of mycorrhizal fungi and frequency of root rot on Pinus strobus seedlings in a southern Ontario nursery, Can J. For. Res. 27 (1997) 54-62.

[52] Ursic M., Peterson R.L., Morphological and anatomical characterization of ectomycorrhizas and ectendomycorrhizas on Pinus strobus seedlings in a southern Ontario nursery, Can. J. Bot. 75 (1997) 2057-2072.

[53] White T.J., Bruns T.D., Lee S.B., Taylor J.W., Amplification and direct sequencing of fungal ribosomal RNA genes for phylogenetics, in: Innis M.A., Gelfand D.H., Sninsky J.J., White T.J. (Eds.), PCR Protocols: a Guide to Methods and Applications, Academic Press, London, 1990, pp. 315-322. 